\title{
Surviving the Onslaught of Globalization: the Last Drops of Sweat of the Traditional Theater of Mendu, West Kalimantan
}

\author{
Gunta Wirawan ${ }^{1}$, Herman J Waluyo ${ }^{2}$, Sarwiji Suwandi ${ }^{3}$ \& Sahid Teguh \\ Widodo 4 \\ ${ }^{1}$ Faculty of Teacher Training and Education, Universitas Sebelas Maret, Surakarta, \\ Indonesia.Email: gwirawan91@student.uns.ac.id \\ 2,3Faculty of Teacher Training and Education, Universitas Sebelas Maret, Surakarta, \\ Indonesia \\ ${ }_{4}^{4}$ Faculty of Cultural Sciences, Universitas Sebelas Maret, Surakarta, Indonesia.
}

\begin{abstract}
Traditional art is often left out by globalization which offers new types of popular culture. As a result, the local culture of a nation slowly began to be abandoned by its supporting community. One of the regional arts that 'lives unwillingly dead do not want to' is the traditional theater of mendu in West Kalimantan. Moving on from these concerns, TiraiBudayaart gallery was formed by artists and community leaders who live in Sungai Duri 1, Sungai Kunyit District, Mempawah Regency, of West Kalimantan. This art gallery strives to preserve their unique culture. Its activities include inviting the younger generation to revive the traditional theater of mendu. The purpose of this study is to describe the role of the TiraiBudaya art gallery in an effort to preserve the traditional theater of West Kalimantan. The method is used is descriptive qualitative, form case study approach. The results of the study were in the form of a description of the role of the TiraiBudayaart gallery in an effort to preserve the traditional theater of mendu as a hereditary heritage which became the cultural treasure of West Kalimantan.
\end{abstract}

Keywords: mendu traditional theater, Tirai Budaya art gallery, conservation.

\section{Introduction}

It cannot be denied that the bad effects of modernization have eroded traditional values in society. As a result, the tradition that was rooted initially was easily uprooted and abandoned by the supporting community. The identity of a nation slowly shifts to become new foreign types of culture.

The flow of globalization can't be avoided (Samidi, 2006: 236) so that the fading of the cultural values of the people is replaced with popular culture (Jefrizal, 2017: 11). This greatly affects to the younger generation who are more comfortable with an instant and practical culture (Angraini, 2015: 89), especially in terms of art. Apparantly in enjoying entertainment, the paradigm of the younger generation has begun to shift from entertainment that is enjoyed collectively to personal forms of entertainment. They think traditional art is outdated.

(C) AesthetixMS 2020. This Open Access article is published under a Creative Commons Attribution Non-Commercial 4.0 International License (http://creativecommons.org/licenses/by-nc/4.0/), which permits non-commercial re-use, distribution, and reproduction in any medium, provided the original work is properly cited. For citation use the DOI. For commercial re-use, please contact editor@rupkatha.com. 
One of the arts that is considered irrelevant to the present time is the traditional theater of West Kalimantan is mendu. In fact, one of the significant elements that gives the beauty of the cultural mosaic in West Kalimantan is the performing arts (Effendi, 2006: 2), but it is forgotten by the supporting community. As an effect of modernization as mentioned above, it turns out that almost all traditional arts also suffered a setback. Especially the younger generation cares no longer about the art of their own region (Kleden-Probonegoro, 2010: 166).

If you look back, a few decades ago, traditional performing arts had an important role in the culture of society. The function of performing arts aside from being entertainment is also as a medium of education, information, communication, social integration, expression of aesthetic feelings, artistic expression, and religious facilities (Achmad, 2006: 103-108, Badrun, 2014: 35, Bin Hj. Abdullah \& Bt. Dato 'Hj. Iskandar, 2017: 155, Paluseri, Syahdenal, \& Ryan, 2014: 214, Taylor, 2007: 10). Traditional performances are able to become an archive of noble values of local wisdom. Performing arts as part of oral traditions are also used in efforts to maintain or establish control over others in the same community (Vansina, 2014: 161).

Why does traditional theater become less attractive by the supporting community? Apart from being impractical, this performance art also seems boring. The younger generation prefers personal entertainment through the internet or personal mobile phones. Entertainment which was originally a collective expression became very individual. In addition, the lack of support from the local government also affects the sustainability of traditional theaters. The creativity and care of artists are the main key, and last but not least is the support of the community owners.

Moving on from that cause concern, a performer named SyamsieJar'ialong with several community leaders in his village tried to gather young people in a traditional art gallery where one of the activities was the traditional theater of mendu. The art gallery was named the TiraiBudaya art gallery, domiciled in Sungai Duri 1 Sungai Kunyit District Mempawah Regency West Kalimantan.

Until now the mendu traditional theater group that still survives only is with the TiraiBudaya art gallery. A condition that is very concerned to considering the mendu has existed since hundreds of years ago. This study aims to describe the role of the Tirai Budaya art gallery in an effort to preserve the traditional theater of mendu as a typical art of West Kalimantan.

\section{Research Methods}

This research is a qualitative research with descriptive method. Descriptive method is a method that expresses, describes, deciphers, illustrates, and explained the object of research (Creswell, 2015: 59). The form of this research is qualitative (Creswell (2015), Yin (2011), Leavy (2017). The research approach used is case studies, seek to examine as much data as possible about the subject under study to describe a case in detail. Yin (2011: 1) states that case studies are suitable if research focus is on contemporary phenomena in real life contexts.

Data in the form of documents, actions, videos and photos were collected. Data collection techniques were carried out by interviews, field observations, data documentation, and documentary analysis. Interviews were conducted with Mr. SyamsieJar'i (64 years old) as the chairman and director of the TiraiBudaya art gallery by twice, namely, on July 21, 2019, and on August 26, 2019 using audio recordings and records. Interviews were also conducted with Mr. Toni Azwar (48 years), one of the actors and founders of the TiraiBudaya art gallery on August 25, 2019. In addition, to strengthen the data, interviews were conducted with several audiences from both 
the elderly and young generation during the mendu performance on 21 August 2019 on the Sungai Duri 1 soccer field. Researchers observe the process of training, preparation, and traditional theater performances at the mendu TiraiBudaya art gallery. Data documentation is the collection of data in the form of video, audio, and picture documentation (photos) for both training and staging the TiraiBudaya art gallery. Documentary analysis is supporting data taken from books, journals, and seminar proceedings.

Data collection tools in this study are humans, the researcher himself as the main tool or instrument. The data obtained were collected and then analyzed systematically through three stages, namely data reduction, data presentation, and drawing conclusions/verification. Data reduction is the process of simplifying, selecting, classifying, and setting aside data that is not in accordance with the formulation of the problem. Presentation of data is a collection of data and information that has been reduced and presented in the form compiled description by systematically. Then the verification or conclusion is based on the research process that has been done.

\section{Results and Discussion}

The Malays in West Kalimantan have a distinctive culture in the form of folk art, known as mendu. In 2014 through the Ministry of Education and Culture of the Republic of Indonesia the traditional theater of mendu has been designated as an 'intangible cultural heritage' shared by the provinces of West Kalimantan and Riau Islands. This must receive a positive appreciation as the government's efforts to maintain and preserve the regional culture which is essentially a national cultural treasure.

\section{A glimpse of the Traditional Theater Mendu West Kalimantan}

Mendu traditional theater originated from Malikian Village of Mempawah Hilir District Mempawah Regency of West Kalimantan Province. Mendu is a traditional Malay theater that combines dance, singing, martial arts, dialogue and play. The play tells a royal story. Mendu begins with a Beladon dance and ends with a Beremas dance. This theater is humorous in dialogue and scenes, but it does not lie in the story-line. The cuteness is shown mainly played by the king's assistant with the titled Khadam (Adam) and played by MakMiskin from the common people. The most prominent feature in the traditional theater mendu is that in every play the truth must defeat the evil.

The name mendu is derived from the name of DewaMendu (Achmad, without the years of publishing: 8o; A. Halim R, 2003: no page number). The idea of this name arose when they were preoccupied with practice before the performance for the first time. At that time the story they were going to play was titled DewaMendu. So, they spontaneously called the art of mendu (Wirawan, 2018: 335).

A similar sentiment was also expressed by Ramli (in Juliastuty, 2014: 36) that in his spare time after serving the community, the youths namely Ali Kapot, Amat Anta, and Achmad along with their students often practiced art. One day they would perform the art performance, but were confused to give the name of the art. It so happened that the story that was first staged was about DewaMendu. Finally they agreed to give the name of the art with the name of mendu.

There are three versions of the origin of the West Kalimantan mendu theater (Wirawan, 2018: 337-338), namely (1) in 1712. In an old book bearing the Arabic Malay letters, it was explained that the art of mendu began to be developed in 1712. The book was kept by Mr. Mukminin Noerman 
(old mendu figure) in Malikian Village of Mempawah Regency (2) 1871. In the book Intangible Cultural Heritage of Indonesia Determination in 2014, it was stated that mendu traditional art was first shown in 1871 by three young men from Mempawah, namely Ali Kapot, Amat Anta, and Achmad. (3) 1876. In West Kalimantan's Mendu Theater book, it is mentioned that three men from Mempawah who migrated to Brunei Darussalam in 1871, namely AmatAntu, Achmad, and Kapot, finally returned to Mempawah in 1876, then developed mendu.

Traditional theater mendu in West Kalimantan experienced ups and downs. At the beginning of its growth the traditional theater of mendu was very popular by the community. But during the Japanese colonialism this theater was never staged at all because of a ban on gathering by the Japanese government. It was only after Indonesia's independence, especially around the 1980-1990s the traditional theater mendu again experienced rapid progress. But unfortunately, in the 2000 returned to decline even almost said to be extinct.

As mentioned above, mendu's traditional theater has been designated as an 'intangible cultural heritage' shared by the West Kalimantan Province and Riau Islands through the establishment of the Ministry of Education and Culture of the Republic of Indonesia in 2014. This government effort is an effort to preserve the regional arts of the Indonesian nation, given the theater mendu traditionally has local wisdom including aesthetic values, education, advice, custom storage media, and community identity as the cultural treasures of the Indonesian people.

\section{Tirai Budaya Art Gallery in the Middle of the Eroded Regional Culture}

TiraiBudaya art gallery was established in 2015 by SyamsieJar'i, Zainal, Suryani (Village Head), and Toni Azwar in Sungai Duri 1 village Sungai Kunyit sub-district Mempawah District in West Kalimantan.

Previously SyamsieJar'i had also established theTabir Budayaart gallery in 2007 in Sungai Duri 2 village, which is now no longer active. The art gallery which had been disbanded was chaired by Mr. Anwar. However, because there were internal disputes between members of the art gallery, especially financial issues that were not transparent, finally the art gallery broke up by itself.

TabirBudaya art gallery which was disbanded in 2011, actually had quite a number of performances, including 2008 in the robo'-robo' event in Mempawah, in 2009 staging in Mempawah, in 2010 in Mempawah, in 2010 again in the Mempawah Regent Hall, in 2010 in Tebedu, the Malaysian border in order to welcome the Minister, in 2010 the staging at Mempawah, the year 2011 in Mempawah in preparation for Solo was held by the Provincial Tourism office, and in 2011 the staging in Solo within the framework of the archipelago theater festival won the hope champion 2.

After SyamsieJar'i moved to domicile in Sungai Duri 1 village, in 2015 a meeting was held to form an art gallery. Although there is no relationship with the TabirBudaya art gallery which was disbanded, the TiraiBudaya art gallery has activities that are almost the same as the TabirBudaya art gallery, namely Malay art, especially the traditional theater of mendu.

TiraiBudaya art gallery was established out of the concern for the young generation in Sungai Kunyit Sub district, which began to forget the distinctive art of their own area. This idea sparked when SyamsieJar'i often saw young people in his village wandering at night. Rather than the young generation doing activities that are less useful, it would be nice if collected in a gathering place of artistic activities. 
This activity is a tangible form of efforts to preserve the traditional theater of mendu. If no concrete step is taken, it is sure that traditional theater will be extinct. According to Syamsiejar'i, the gathering place formed the theatre gallery that would facilitate coaching and management. Therefore, in order for this art gallery to be formal and have legal force, an operational permit is issued by the Tourism Office of Mempawah Regency and West Kalimantan Province. It is also strengthened by a notarial deed and has Taxpayer Registration Number (NPWP).

In addition, it is undeniable that this art gallery was formed to treat people's longing for the arts that were once the favorite in their village, especially for parents. Not only that, some viewers from the younger generation also claimed to have found out the distinctive arts that their parents had told. In general, the purpose of the community watching mendu is solely to enjoy entertainment.

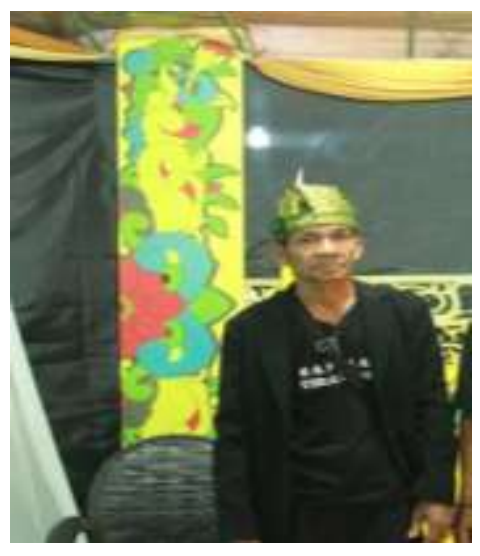

Syamsie Jar'i

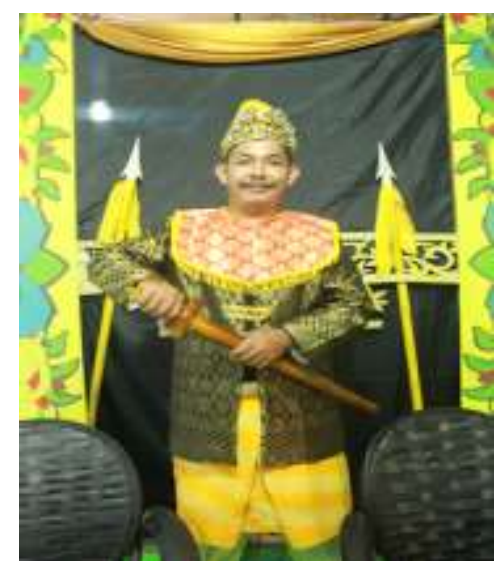

Toni Azwar

Source: personal document

Figure 1: Photo of the founder of the TiraiBudaya art gallery

TiraiBudaya art gallery is chaired by SyamsieJar'i. Besides being a script writer (synopsis) he also doubles as a director in mendu's traditional theater. TiraiBudaya art gallery's activities include several Malay arts including the traditional mendu theater, jepin dance, hadrah, kasidah, and folk songs. In order to keep the art gallery's activities alive, regular training schedules are held. Especially for the traditional theater mendu every Wednesday night and Friday nights. This exercise is done even though not preparing for a performance. However, if there is a staging schedule, the training will be even more intensive.

Table 1: The training proses for Kerajaan Langkadura's performance

\begin{tabular}{cllll}
\hline No & \multicolumn{1}{c}{ Date and time } & \multicolumn{1}{c}{ Activity } & Number of Present & \multicolumn{1}{c}{ Information } \\
\hline 1 & Wednesday, July 31 2019 & $\begin{array}{l}\text { Direction from the } \\
\text { director and first } \\
\text { practice }\end{array}$ & 21 people & $\begin{array}{l}\text { Almost all the cast } \\
\text { and crew were } \\
\text { present }\end{array}$ \\
\hline 2 & Friday, August 2, 2019 & Second exercise & 15 people & $\begin{array}{l}\text { The main player } \\
\text { and several } \\
\text { supporting cast }\end{array}$ \\
\hline 3 & $\begin{array}{l}\text { Wednesday, August 7, } \\
\text { 2019 }\end{array}$ & Third exercise & 7 people & Main cast \\
\hline 4 & Friday, August 9, 2019. & Fourth exercise & 7 people & Main cast \\
\hline
\end{tabular}




\begin{tabular}{cllcl}
\hline 5 & $\begin{array}{l}\text { Wednesday, August 14, } \\
\text { 2019 }\end{array}$ & Fifth exercise & 20 people & $\begin{array}{l}\text { The main cast and } \\
\text { supporting cast }\end{array}$ \\
\hline 6 & Friday, August 16, 2019 & Sixth exercise & 23 people & All cast and crew \\
\hline 7 & Sunday, August 18, 2019 & Rehearsal & 26 people & $\begin{array}{l}\text { All cast and crew } \\
\text { present }\end{array}$ \\
\hline
\end{tabular}

The performance of the "Kerajaan Langkadura" was held on Wednesday, August 21, 2019 at Sungai Duri 1 soccer field, in the framework of the Republic of Indonesia Anniversary and Tirai Budaya art gallery's anniversary, played by 23 actors, concurrently 5 music players, and 7 dancers and assisted by 3 crew who served the sound systems, lighting, and equipment. The total cast and crew involved were around 26 people.

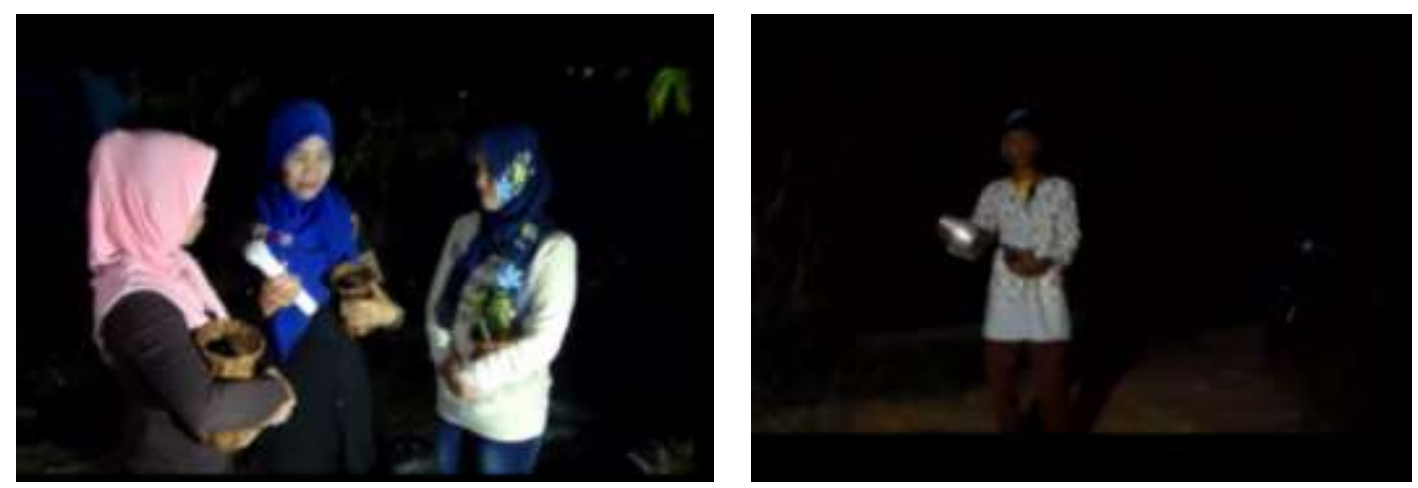

Source: personal document

Figure 2:The process of mendu traditional theater training

Until now, the TiraiBudaya art gallery has been performed ten times: five time performances on their own initiative, and five times at the invitation of the District Government of Mempawah. Generally the performances are held on an open field stage, except once in the Opu Daeng Manambon Mempawah sports building (GOR) and once at the TiraiBudaya art gallery's house. The plays they have performed are as follows.

Table 2: Performance of the TiraiBudayaart gallery

\begin{tabular}{|c|c|c|c|c|}
\hline No & The date & Title play & The place & Event \\
\hline 1 & $\begin{array}{l}20 \text { Agustus } \\
2015\end{array}$ & Antah Barantah & Sungai Duri 1 & $\begin{array}{l}\text { Inauguration of TiraiBudaya art } \\
\text { gallery }\end{array}$ \\
\hline 2 & 9 Januari 2016 & $\begin{array}{l}\text { Hilangnya } \\
\text { Mahkota }\end{array}$ & Kuala Mempawah & $\begin{array}{l}\text { Robo'-Robo' event } \\
\text { andMempawah's anniversary }\end{array}$ \\
\hline 3 & $\begin{array}{l}20 \text { Agustus } \\
2016\end{array}$ & Nyiur Mahkota & Sungai Duri 1 & $\begin{array}{l}\text { Republic of Indonesia } \\
\text { Anniversary and TiraiBudaya art } \\
\text { gallery's anniversary }\end{array}$ \\
\hline 4 & 14 Januari 2017 & $\begin{array}{l}\text { Bambu } \\
\text { Menangis }\end{array}$ & $\begin{array}{l}\text { Opu Daeng Manambon } \\
\text { Mempawah Sports Hall }\end{array}$ & Mempawah's anniversary \\
\hline 5 & $\begin{array}{l}20 \text { Agustus } \\
2017\end{array}$ & Al Wathan Raya & Sungai Duri 1 & $\begin{array}{l}\text { Republic of Indonesia } \\
\text { Anniversary and TiraiBudaya art } \\
\text { gallery's anniversary }\end{array}$ \\
\hline 6 & $\begin{array}{l}28 \text { Oktober } \\
2017\end{array}$ & $\begin{array}{l}\text { Bambu } \\
\text { Menangis }\end{array}$ & Sungai Kunyit & $\begin{array}{l}\text { commemorating of Youth Oath } \\
\text { Day }\end{array}$ \\
\hline
\end{tabular}


Surviving the Onslaught of Globalization: the Last Drops of Sweat of the Traditional Theater of Mendu, West Kalimantan

\begin{tabular}{lllll}
\hline 7 & 18 April 2018 & $\begin{array}{l}\text { Environmental } \\
\text { cleanliness } \\
\text { (short duration } \\
\text { staging) }\end{array}$ & $\begin{array}{l}\text { Sungai Kunyit district } \\
\text { office hall }\end{array}$ & $\begin{array}{l}\text { Welcoming guests from three } \\
\text { companies that will build the } \\
\text { International Port of Kijing }\end{array}$ \\
\hline 8 & $\begin{array}{l}20 \text { Agustus } \\
2018\end{array}$ & Raja Galau & Sungai Duri 1 & $\begin{array}{l}\text { Republic of } \\
\text { IndonesiaAnniversary and } \\
\text { TiraiBudaya art } \\
\text { gallery'sanniversary }\end{array}$ \\
\hline 9 & 14 April 2019 & $\begin{array}{l}\text { Hikayat Dewa } \\
\text { Mendu }\end{array}$ & $\begin{array}{l}\text { at the TiraiBudaya art } \\
\text { gallery's house }\end{array}$ & $\begin{array}{l}\text { Staging for University guests } \\
\text { from Malaysia }\end{array}$ \\
\hline 10 & $\begin{array}{l}21 \text { Agustus } \\
\text { 2019 }\end{array}$ & Kerajaan & Sungai Duri 1 & $\begin{array}{l}\text { Republic of Indonesia } \\
\text { Anniversary and TiraiBudaya art } \\
\text { gallery's anniversary. }\end{array}$ \\
\hline
\end{tabular}

Like other traditional theaters, mendu is also performed without text. Usually script writers only make a synopsis of the story that will be played. The rest depends on demanded improvisation and creativity of the players both dialogue and acting. This means that players are required to be truly adept at conducting dialogues in the Mempawah Malay regional language without memorizing the text of the manuscript.

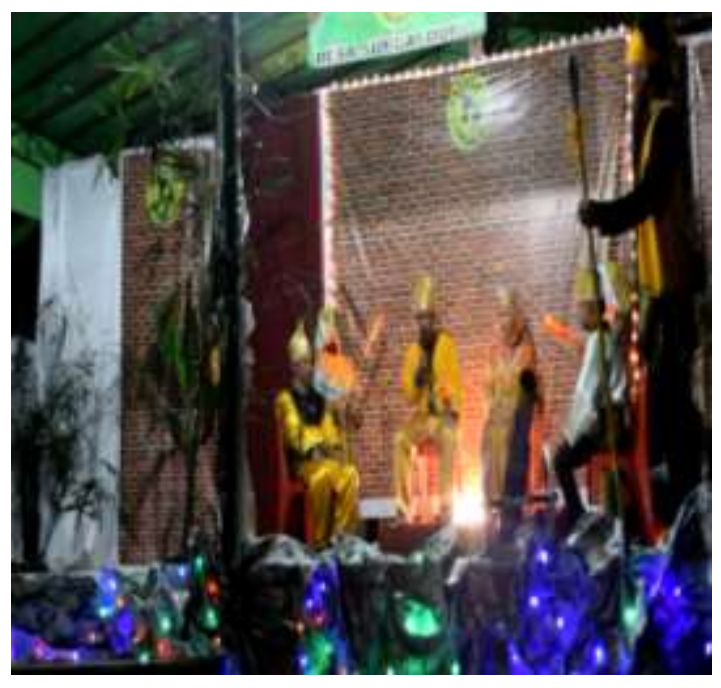

Figure 3: Performing mendu

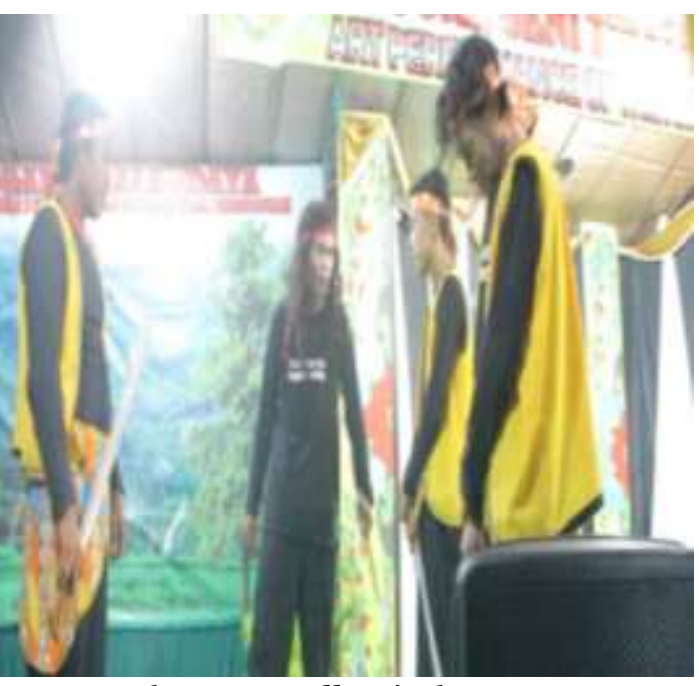

TiraiBudaya art gallery's document

Mendu plays always presents stories about the kingdom of fictional setting. To attract the interest of the audience, the play presented by the TiraiBudaya art gallery is combined with the current context, for example, tucked in about the dangers of drugs or forest fires. Thus, the function of traditional theater as a medium of education and public education can be inserted. This is where the values of local wisdom can be socialized back to the audience.

Traditional theater performances are quite expensive if all the equipments, costumes, stage decorations, and lightings are done to the maximum. To get around the cost, TiraiBudaya art gallery tries to show a simple performance. The stage is made of wood material (floor boards); the back wall is usually installed as billboards or curtains given banners bearing the name of the art gallery. The left and right sides of the stage were deliberately left open so that the audience was more flexible to watch from all directions. The stage roof usually uses tarp. All stage materials are 
gathered by means of rent. The stage is adapted to the play, usually only one set, but has also been lined up to three sets. There is no set standard for stage size that is ideal for a performance. The size of the stage is solely based on the direction of the director, adjusting to the extent of the field, the number of players who will perform, the placement of musical equipment, and the available funds.

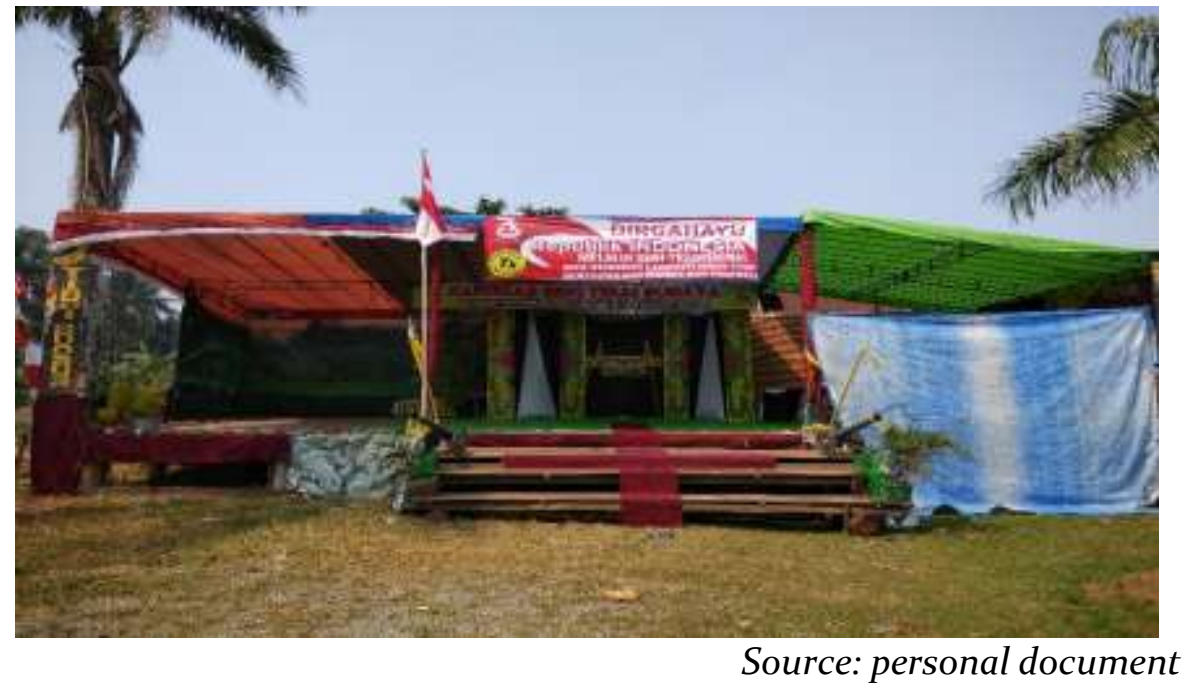

Figure 4: Stage for Mendu's performance

The role of Sungai Duri 1 Village Head is quite big in the effort to preserve mendu. This was proven when the position of village head was held by Mr. Suryani who took the initiative to initiate the establishment of the TiraiBudaya art gallery. This was also continued by his successor who now also has an interest in the development of the mendu. For each performance, a fund of five million rupiah is given. Unfortunately there has been no assistance from the district government of Mempawah. However, the District Government of Mempawah has provided guidance by inviting them to certain events such as Mempawah's anniversary or robo'-robo' events. The regency government always gives honorarium whenever invited to perform.

Players do not get honorarium either during practice or staging. Just occasionally if they are invited by certain parties, and even then it must be shared equally among all players so that the wages they get are also small relatively. They play voluntarily without expecting anything in return or reward because on average they are called to develop the soul of art and on the basis of the awareness of preserving their native culture. This seems to be one of the factors that determines an art gallery that can hold out for long time. Lots of art galleries cannot developed due to financial problems. The players are not given awards in the form of adequate rewards. It merely obtains inner satisfaction after the performance has been successfully performed. While on the other hand the actors need a living expense that is not small, even though their jobs are average as farmers, fishermen and unskilled laborers. If they work to get results and if they do not work (for example because they are preparing to perform) there is certainly no income. They should have obtained material benefits (wages) because the contributions they make are also very time-consuming and tiring. The problem that arises then is who will pay for their sweat? Is the art gallery a shelter (which also does not have sufficient cash), or the local government (which also does not prepare a special fund for coaching)? Clearly, this problem becomes urgent for the sustainability of an art gallery.

The TiraiBudaya art gallery has received assistance from the central government through the Indonesian Ministry of Education and Culture in the amount of Rp. 77,000,000 in 2018. The 
funds are managed for the purpose of purchasing musical instruments, complete costumes $(42$ sets), a complete set of sound systems, and other art gallery needs. Until now the TiraiBudaya art gallery has 3 sets of clothes for the performance.
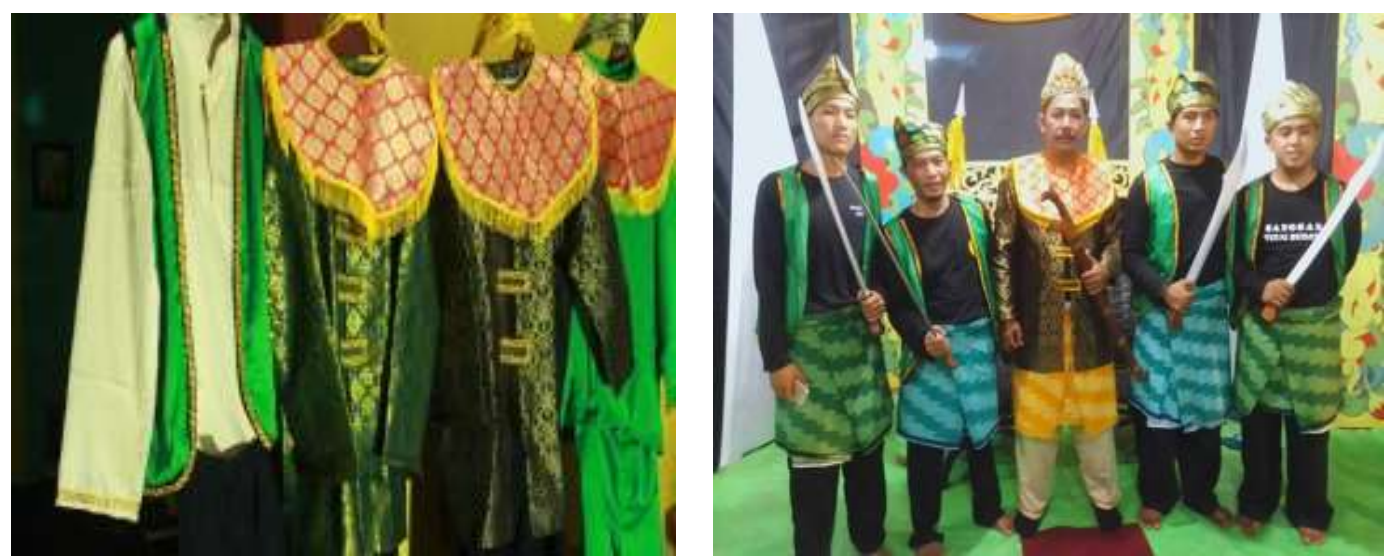

Source: TiraiBudaya art gallery's document

Figure 5: King and bodyguard costume

The instruments that are used to accompany the performance are very simple and traditional. In the past, in the early days of the emergence of mendu, the instruments used tawaktawak (gong), drums, and violins, sometimes also using kesong-kesong (Chinese puppet violins). At the TiraiBudaya art gallery, the musical instruments they use are violin, drum, gong, keyboard, and sometimes sexepon. Music players are an integral part of the show, not stand-alone or separate from the players. Therefore, the placement of musical instruments is also on the stage, usually in a corner of the stage.
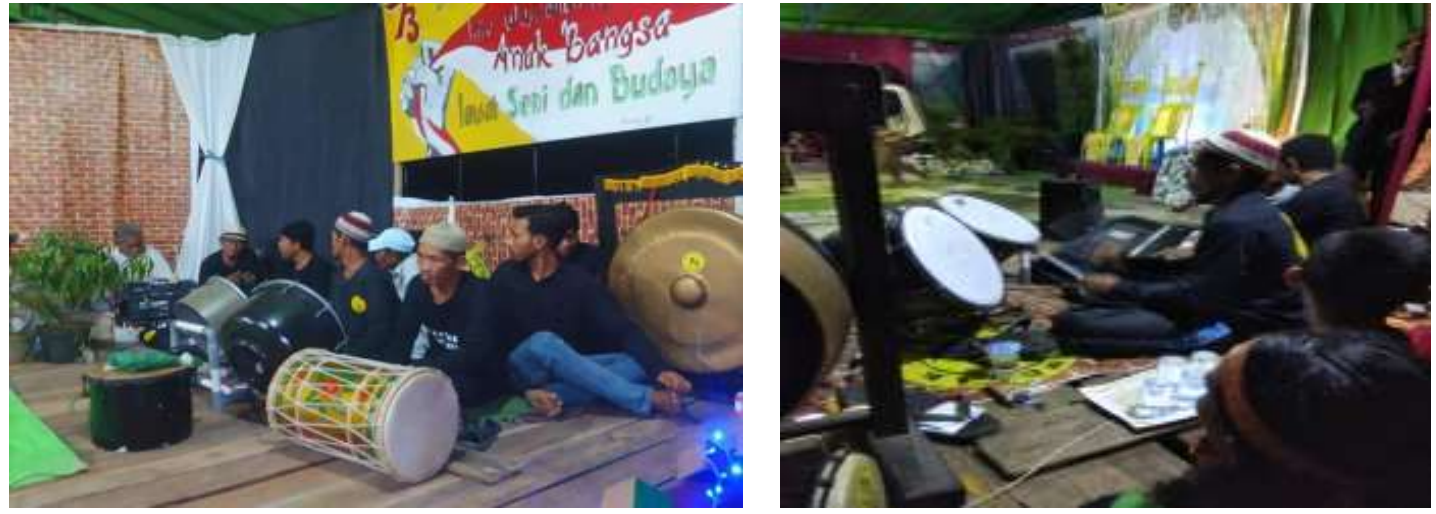

Source: TiraiBudaya art gallery's document

Figure 6: Music player

The players are expected to be versatile in all things staging. Frequently they take double roles and do multiple tasks. For example, Syamsiejar'i, in addition to playing the role of DatokPetala Guru, also works as a director and screenwriter. Similarly, in other roles, it could be the role of warriors and concurrently as a music player. In the performance, they are also required to use cosmetics for cosmetology and sometimes the players will help each other in doing make-up for their friends. 
Mendu is always shown at night; so it requires lighting in every performance. Based on several observations in the process of finding data, the researcher witnessed the lighting was done without adequate lighting techniques. In general, there is no play of light to support the atmosphere at the time of the performance, for example when the genie is released or a scary atmosphere the lights are not dimmed, or when the king sits on the throne spot light is not used. To beautify the stage decoration, sometimes a twinkling series light is used. The lamp used for lighting is neon approximately 100 watts hanging in the four corners of the stage.

The audience is free from being charge. This is one of the strategies of the TiraiBudaya art gallery to attract the audience's interest in watching the mendu show. In the performance, the actors always involve the audience especially the role of Khadam or Mak Miskin; often there is a dialogue between the audience and Khadam so that the atmosphere of the performance seems familiar and funny. Involvement of the audience in the performance can also occur, for example, when the king gives gifts to several spectators, as if the king was serving his people. Involving the audience in the show is one of the hallmarks of traditional mendu theater.

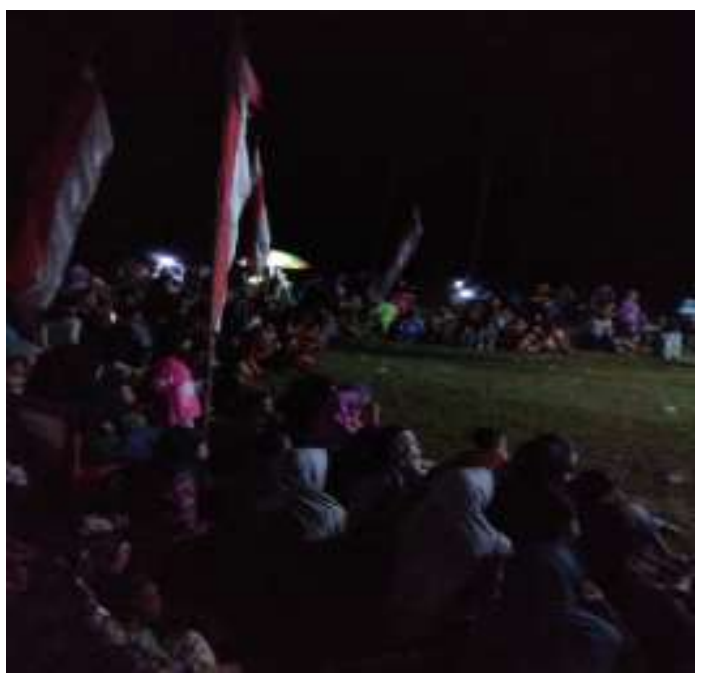

Figure 7: People watch the mendu performance

As observations made by researcher during two performances, namely on August 20, 2018 the play "Raja Galau" in the context of the Republic of Indonesia Anniversary and the anniversary of the TiraiBudaya art gallery in the Sungai Duri soccer field 1, and on August 21, 2019 the "Kerajaan Langkadura" in Sungai Duri 1 soccer field, the enthusiasm of the community was very high to watch mendu. The show started at around 20:0o West Indonesia Time, began with Malay dance to open the program, after which the master of ceremonies read a synopsis of the story, followed by introducing the performers. All the players got on the stage, and then the scene began by displaying a Khadam figure that made the audience laugh. The story line went according to the synopsis and direction of the director to complete.

According to researcher's observations, no less than 400 to 500 people thronged the field around the scaffolding. Only unfortunately, this number only lasts up to half the show (about 1 hour), one by one the audience left the location of the stage. Until the performance was finished, no more than 50 people were still watching. Some of the audience members who were interviewed said that they were less satisfied because the mendu that they were witnessing now was quite different from the mendu they had witnessed. This is recognized by SyamsieJar'i, who deliberately 
eliminated the old grip because of the time that did not allow it. In the past, mendu could be performed continuously for 3 nights and even 7 nights.

As for young people, they are interested in coming to the location because they see many people gathering there. Although some of them also already know that there will be a mendu staging held from announcements and pamphlets that are distributed. The youths were interested in watching mendu because they were curious about what the art was like, although many of them who watched the show did not finish it because they felt bored with the unattractive storyline. But one young man named Deo (24 years) claimed to want to join the TiraiBudayaart gallery to participate in preserving their culture.

TiraiBudaya art gallery has tried its best to survive in the midst of the swiftness of modern culture by always actively training both the traditional theater of mendu, kasidah, hadrah, and folk songs (Malay). Sometimes the members of the art gallery gather to do an evaluation of the activities they have done or just gathering for drinking coffee. They always take care of togetherness for the sake of the sustainability of their proud of art gallery.

\section{Conclusion}

TiraiBudaya art gallery is the only traditional theater group of mendu which is still active. Some of the mendu art gallerys in the West Kalimantan province have been non-existent and no longer performing. To preserve the traditional theater of mendu there must be a serious effort from various parties, both the local government, cultural figures, artists, and supporting communities. In addition, for the art gallery to be able to survive, special attention must be paid to the welfare of the players supported by local government funding in each district/city.

\section{References}

A. Halim R (ed). (2013). Mendu Teater Rakyat Kalimantan Barat. Manuskrif. Unpublished paper.

Achmad, A.K. (2006). Mengenal Teater Tradisional di Indonesia. Jakarta: Dewan Kesenian Jakarta.

Achmad, A.K., Ganda, Y., Rochyatmo, A., \& Mujiono (ed). (without the years of publishing). Ungkapan Beberapa Bentuk Kesenian (Teater, Wayang dan Tari). Jakarta: Direktorat Kesenian, Proyek Pengembangan Kesenian Jakarta, Depertemen Pendidikan dan Kebudayaan Republik Indonesia.

Anggraini, P. \& Kusniarti, T. (2015). The Insertion of Local Wisdom into Instructional Materials of Bahasa Indonesia for 1oth Grade Students in Senior High School. Journal of Education and Practice. 6 (33), 8992.

Badrun, A. (2014). Patu Mbojo. Mataram: Penerbit Langge.

Bin Hj. Abdullah, Z., \& Bt. Dato' Hj. Iskandar, S.A. (2017). Visual Dimension in the Performing of Makyung Raja Besar Ho Gading. International Journal of Academic Research in Economics and Management Sciences. 6 (4), 154-161.

Cresswell, J.W. (2015). Penelitian Qualitatif \& Desain Riset. Memilih di antara Lima Pendekatan. Terj. Ahmad Lintang Lazuardi. Yogyakarta: Pustaka Pelajar. 
Effendy, C. (2006.b). Sastra Sebagai Wadah Integrasi Budaya. Pontianak: STAIN Press.

Jefrizal. (2017). Relevansi Kehidupan Sehari-hari dengan Seni Pertunjukan Tradisional. Jurnal Ilmu Budaya. $14(1), 11-21$.

Juliastuty, D. (2014). Dinamika Teater Tradisional Mendu di Kalbar: Patanjala. 6 (1), 33-48.

Kleden-Probonegoro, N. (2010). Mamanda Theatre, the Play of Banjar Culture. Wacana. 12 (1), 162-180.

Leavy, P. (2017). Qualitative, Quantitative, Mixed Method, Art-Based, and Community Based, Participatory Research Approaches. New York: The Guilford Press.

Paluseri, D.D., Syahdenal, L.M., \& Ryan. (2014). Warisan Budaya Takbenda Indonesia Penetapan Tahun 2014.Jakarta: Direktorat Internalisasi Nilai dan Diplomasi Budaya, Direktorat Jenderal Kebudayaan, Kementerian Pendidikan dan Kebudayaan Republik Indonesia.

Samidi. (2006). Teater Tradisional di Surabaya 1950-1965: Relasi Masyarakat dan Rombongan Seni: Humaniora. 18 (3), 236-245.

Taylor, R. (2007). Turning up the Volume: A Study of the Wan Smolbag Theatre Company. $3 \mathrm{~L}$ Journal of Language Teaching, Linguistics and Literature. 13, 9-29.

Vansina, J. (2014). Tradisi Lisan Sebagai Sejarah. Terj. Astrid Reza, dkk. Yogyakarta: Ombak. (Buku asli diterbitkan 1985).

Wirawan, G. (2018). Sejarah Mendu Kalimantan Barat. Dalam Emzir dan Djamari (ed.). Proceeding Seminar Nasional Bahasa dan Sastra: Mengukuhkan Fungsi Bahasa dan Sastra untuk Memperkuat Jati Diri Bangsa. hlm. 329-338. Jakarta: LIPI Press.

Yin, R.K. (2011).Qualitative Research:form Start to Finish. New York: The Guildford Press.

Wang, I-Chun. (2013). "Globalization and Theater Spectacles in Asia." CLCWeb: Comparative Literature and Culture 15.2

C.B. Balme, B. Szymanski-Dull (eds.), Theatre, Globalization and the Cold War, Transnational Theatre Histories, DOI 10.1007 / 978-3-319-48084_10 